\title{
A middle Eocene mesoeucrocodylian (Crocodyliformes) from the Kaninah Formation, Republic of Yemen
}

\author{
Nancy J. Stevens ${ }^{1,,, c}$, , Robert V. Hill ${ }^{2, c}$, Mohammed Al-Wosabi ${ }^{3}$, \\ Anne Schulp ${ }^{4}$, Mustafa As-Saruri ${ }^{5}$, Fuad Al-Nimey ${ }^{6}$, Lea Ann Jolley ${ }^{7}$, \\ Yvonne Schulp-Stuip ${ }^{8}$, Patrick O'Connor ${ }^{9, c}$
}

${ }^{1}$ Ohio Center for Ecology and Evolutionary Studies and Department of Biomedical Sciences, 228 Irvine Hall, Heritage

College of Osteopathic Medicine, Ohio University, Athens, Ohio 45701, U.S.A.; e-mail: stevensn@ohio.edu

${ }^{2}$ Department of Anatomy, New York Institute of Technology College of Osteopathic Medicine, Northern Boulevard, Old Westbury, NY 11568-8000, U.S.A; e-mail: rhill01@nyit.edu

${ }^{3}$ Earth \& Environmental Sciences Department, Faculty of Science, Sana'a' University, P. O. Box 11903, Sana'a, Yemen; e-mail: ma_wosabi@yahoo.com

${ }^{4}$ Natuurhistorisch Museum Maastricht, De Bosquetplein 6-7, 6211 KJ Maastricht, The Netherlands, and Faculty of Earth and Life Sciences, Amsterdam VU University, De Boelelaan 1085, 1081 HV Amsterdam, The Netherlands; e-mail: anne.schulp@maastricht.nl

${ }^{5}$ Ministry of Oil and Minerals, Tahreer Post Office, P. O. Box 3867, Sana'a, Yemen; e-mail: msaruri@fulbrightmail.org;

${ }^{6}$ Yemen Geological Survey, Algeria Street, PO Box 15755, Sana'a, Yemen; e-mail: geofuad@hotmail.com

${ }^{7}$ Department of Biology, Department of Biology, Utah State University, Uintah Basin Regional Campus, 320 N Aggie Blvd., Vernal, UT 84078-8330, U.S.A.; e-mail: 1.jolley@aggiemail.usu.edu

${ }^{8}$ Bemelerweg 30, 6226 HA Maastricht, The Netherlands; e-mail: yvonnestuip@mac.com

${ }^{9}$ Ohio Center for Ecology and Evolutionary Studies and Department of Biomedical Sciences, 228 Irvine Hall, Heritage

College of Osteopathic Medicine, Ohio University, Athens, Ohio 45701, U.S.A.; e-mail: oconnorp@ohio.edu "Corresponding author

'These authors contributed equally to the manuscript

\begin{abstract}
During the Cenozoic, the Arabian Plate separated from continental Africa and assumed a closer geographical relationship with Eurasia. As such, the vertebrate fossil record of the Arabian Peninsula has great potential for documenting faunal interchanges that occurred as a result of such tectonic events, with a shift from a primarily Afro-Arabian fauna in the Palaeogene to a more cosmopolitan fauna in the Neogene. Understanding of the sequence and timing of this faunal interchange has long been hampered by a lack of palaeontological data. Recently recovered fossils from the Middle Eocene Kaninah Formation of Yemen constitute the earliest Palaeogene record of continental vertebrates from the Arabian Peninsula, thereby offering a rare glimpse at the region's post-Cretaceous fauna. Here we describe fossil materials from the Kaninah Formation, a collection of dental and postcranial elements representing a mesoeucrocodylian crocodyliform of unclear affinities. The specimen exhibits ziphodont tooth morphology along with a biserial paravertebral shield and polygonal gastral osteoderms, consistent with certain mesoeucrocodylians (e.g., ziphodontan notosuchians). Yet the associated fragmentary anterior caudal vertebra, although badly abraded, preserves morphology suggestive of procoely. This vertebral type in combination with the dental and osteoderm morphology is much more taxonomically restrictive and consistent with the suite of characters exhibited by atoposaurids, a finding that would significantly extend that clade through the Cretaceous/Palaeogene boundary. Alternatively, given the relative paucity of information from the region during the Palaeogene, the combination of characteristics of the Kaninah crocodyliform may reflect a novel or poorly
\end{abstract}


known form exhibiting previously unrecognised character mosaicism. We take a conservative approach, and refer the Kaninah specimen to Mesoeucrocodylia, Atoposauridae (?) pending discovery of more complete material. New fossils recovered from the Kaninah Formation raise unanticipated questions about the longevity of Mesozoic clades, underscoring the role that the region may play in revealing novel occurrences, relictual forms, and evidence of faunal dispersals from this critical interval in vertebrate evolutionary history.

Key words: Mesoeucrocodylia, atoposaurid, crocodyliform, Eocene, Kaninah Formation, Yemen

\section{Introduction}

The early Cenozoic was an interval of great geological upheaval in the region now known as the Arabian Peninsula, with increasing tectonic activity culminating in the Arabian plate separating from the African continent and eventually colliding with Eurasia. Fossiliferous deposits throughout this interval record a fascinating alternation of marine transgressions and regressions, represented by marine limestones and sandstones with the occasional continental depositional unit (As-Saruri, 1998).

The palaeontological history of Yemen remains relatively undocumented (Jacobs et al., 1998), although recent exploration has resulted in the discovery of important Mesozoic dinosaur trackways, with bipedal tracks attributed to a large ornithopod dinosaur, and quadrupedal tracks attributed to a herd of over a dozen sauropods travelling together across a coastal mudflat (Schulp et al., 2008). Here we report results of additional palaeontological reconnaissance efforts by the Yemen Paleontology Project (a collaboration among Yemeni, US, and European institutions) aimed at increasing geological and palaeontological sampling of an important early Cenozoic window into the Earth's past.

\section{Geological setting}

Fossils described in the present contribution were discovered in the Kaninah Formation in south-central Yemen (Fig. 1), a lateral lithological equivalent of the marine Habshiya Formation that is well dated as Lutetian, based on invertebrate micro- and macrofaunal biostratigraphy (Beydoun, 1966). The Kaninah Formation conformably overlies the early Eocene Rus Formation, and a middle Eocene age for the
Kaninah localities is consistent with plants and sirenian mammals recovered there (As-Sururi et al., 1999).

The Kaninah Formation was first described by As-Saruri $(1995,1996,1998)$ to detail the Kaninah-Jizwal succession (As-Saruri \& Langbein, 1994, 1995) and was later formalised in the international lexicon of stratigraphy by Beydoun et al. (1998). The structural framework of the sedimentary basin follows Beydoun et al. (1996) and Beydoun \& As-Saruri (1998) with the Middle Eocene Kaninah Formation facies located in the Hajr sector of the Sab'atayn Basin. The formation represents a transitional facies situated between the fully marine Habshiyah Formation of the Jiza'-Qamar Basin in the East, and the fully terrestrial Mayfa'ah Formation of the Balhaf Basin in the West.

\subsection{Lithology and microfacies of the Kaninah Formation}

The type section of the Kaninah Formation is approx. $135 \mathrm{~m}$ thick (Fig. 2), with $\sim 80 \mathrm{~m}$ of the formation also exposed near Jizwal. The base of the Kaninah Formation is represented by the Transitional Beds Member, a unit that consists of alternating papery shale and chalky to marly limestone. This member is deposited across a relatively large area that stretches to the Al-Mahfid uplift in the West, reflecting a large-scale marine transgression during the middle Eocene.

The Kaninah Formation consists of intercalated sandy limestones, sandstones and papery shales (Fig. 2). The sandy limestones often contain brachiopods, gastropods and molluscs. The sandstones are characterised by lamination and cross-bedding, and often contain silicified and petrified wood. Ferrogenous silcretes cap some of the sandstone horizons. Most of the 
Fig. 1. Location of the middle Eocene palaeontological field area in south-central Yemen (indicated by star).

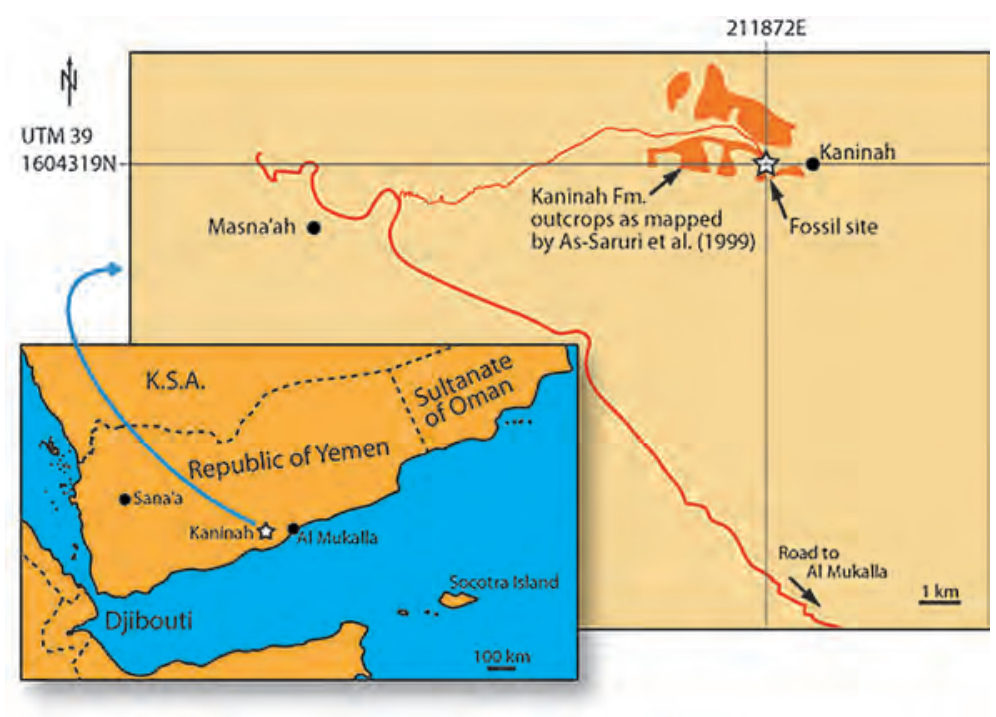

sandstones are cemented with sparry calcite; those that are not cemented appear to reflect aeolian depositional units. The papery shales are finely laminated, 2-3 m thick, and light green in colour, although brownish-greyish horizons with secondary gypsum also occur.

Different microfacies types were successively deposited in the Kaninah Formation. At the base, limestone represents a fossiliferous packstone facies containing foraminifera, gastropods and algae. The middle of the section is characterised by a widespread bioclastic packstone preserving brachiopods and gastropods. Fruits, seeds and vertebrate fossils have also been described from the middle of the Kaninah Formation (As-Saruri et al., 1998, 1999). The upper part of the formation is a fossiliferous packstone characterised by different kinds of invertebrate shell fragments and algae.

Identifiable fossils are abundant in sandstone layers, with plant and invertebrate materials detailed elsewhere (e.g., As-Saruri et al., 1998). The continental deposits of the Kaninah Formation are fossiliferous in the succession at Kaninah itself, and are characterised by fruits and seeds (Liliaceae, Anonaceae, Anonaspermum sp. and Nymphaeaceae, Thiebaudia rayanensis), and by fluvial/estuarine to shallow-marine vertebrates (As-Saruri et al., 1998, 1999; this study). The flora and fauna of the Kaninah Formation indicate the proximity of a continental, forested area to a shallow, tropical sea. Indeed, the Kaninah Formation vertebrates recovered by our team include turtles, crocodyl-

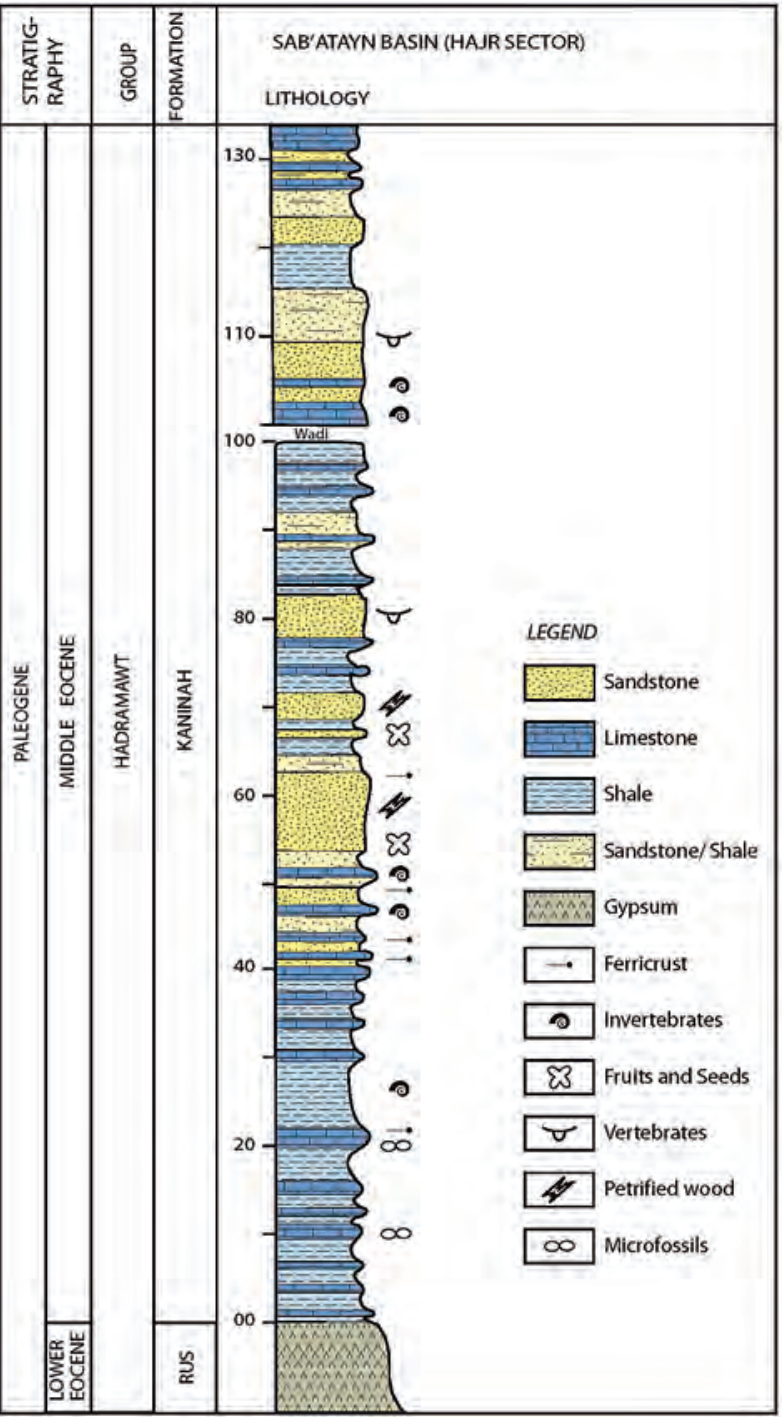

Fig. 2. Detailed stratigraphic section of the Kaninah Formation, with lithologies and fossiliferous horizons noted in the key. 
iforms and sirenian mammals. The most complete vertebrate materials collected to date are the associated crocodyliform dental and postcranial elements that constitute the focus of the present contribution.

\section{Methods}

Fossil vertebrate specimens were hand-quarried in the field and prepared at the Ohio University Paleobiology Specimen Preparation Facility. Measurements were recorded using a Nikon SMZ 1500 stereomicroscope bundled with SPOT Advanced (version 3.5) software. The accuracy of the measurements is on average $\pm 0.01 \mathrm{~mm}$. Reference specimens and casts were examined from collections in the Ohio University Vertebrate Collections and the American Museum of Natural History. Comparisons were supplemented with published photographs for less accessible taxa.

\section{Systematic palaeontology}

Crocodylomorpha Walker, 1970

Crocodyliformes Hay, 1930 (sensu Clark, in Benton \& Clark, 1988)

Mesoeucrocodylia Whetstone \& Whybrow, 1983

?Atoposauridae Gervais, 1871

(Figs 3-4)

Material: An isolated tooth crown; a fragmentary anterior caudal vertebra; two partial left mid-dorsal or caudal dorsal ribs; a partial left ilium; a partial right paramedian dorsal osteoderm; a gastral (ventral) osteoderm.

Diagnosis: The material is referred to Mesoeucrocodylia on the basis of the morphology of the osteoderm, which is consistent with an open paravertebral shield. We tentatively refer it to Atoposauridae on the basis of the following combination of characters: a ziphodont tooth crown; what appears to be a procoelous anterior caudal vertebral centrum; dorsal osteoderms characteristic of a biserial, open dorsal shield; and polygonal gastral osteoderms.

Description: All specimens were found in the field within $25 \mathrm{~cm}$ of one another. In addition, the relative size and condition of the preservation indicate that the crocodyliform material represents a single individual.

The single preserved tooth crown (Fig. 3A, B) exhibits ziphodont morphology; it is strongly compressed buccolingually with distinct mesial and distal carinae. The carinae are serrated, with regularly spaced denticles occurring approximately every $0.125 \mathrm{~mm}$ (i.e., 8 denticles per millimetre). The denticle morphology and cross-sectional profile closely resemble a maxillary tooth described by Lauprasert et al. (2011) and referred to the atoposaurid genus Theriosuchus.

A partial caudal vertebra (Fig. 3C, D) includes the caudal half of the centrum, the pedicles, and the base of each transverse process. The spinous process and the tips of the transverse processes are missing. The caudal end of the centrum, although abraded, is rounded and convex, suggesting a procoelous condition and semi-spheroidal intervertebral articulation. Among crocodyliforms, procoely is most notably a synapomorphy of Eusuchia (Salisbury et al., 2006); the condition occurs, however, in several other more basal clades, including atoposaurids and some 'protosuchians'.

Two partial left ribs are preserved (Fig. 3E). One of these preserves only the tuberculum and a short area proximal to it. The other is more complete, comprising a curved shaft and well-defined tuberculum for articulation with a vertebral transverse process. Diverging from the tuberculum, the process that would have ended as the capitulum is broken. The shaft of the rib is thick and square in cross-section proximally, and becomes flattened into a thin flange distally. Because the capitulum and tuberculum are confluent at their bases, instead of widely spaced forming a Y-shaped divergence, these ribs are interpreted to be from the mid-dorsal to caudal dorsal region.

The partial left ilium (Fig. 3F, G) includes the broken bases of the anterior and posterior processes and a portion of the acetabulum. In lateral aspect, the acetabulum is shallow and the supra-acetabular ridge is relatively straight and flat. The peduncles of the ischium and pubis are not clearly discernible. In medial view, articular surfaces for the two sacral ribs are visible. 


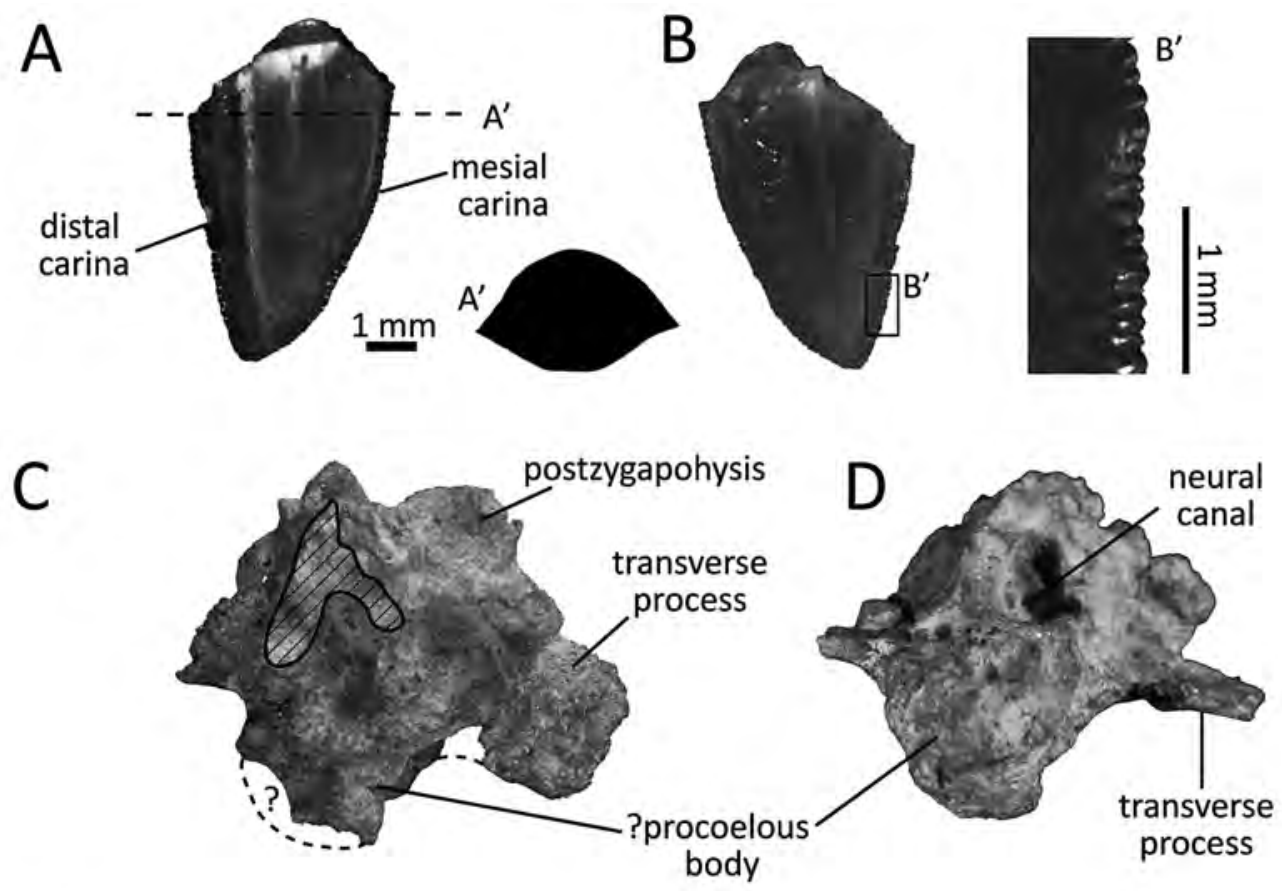

E tuberculum
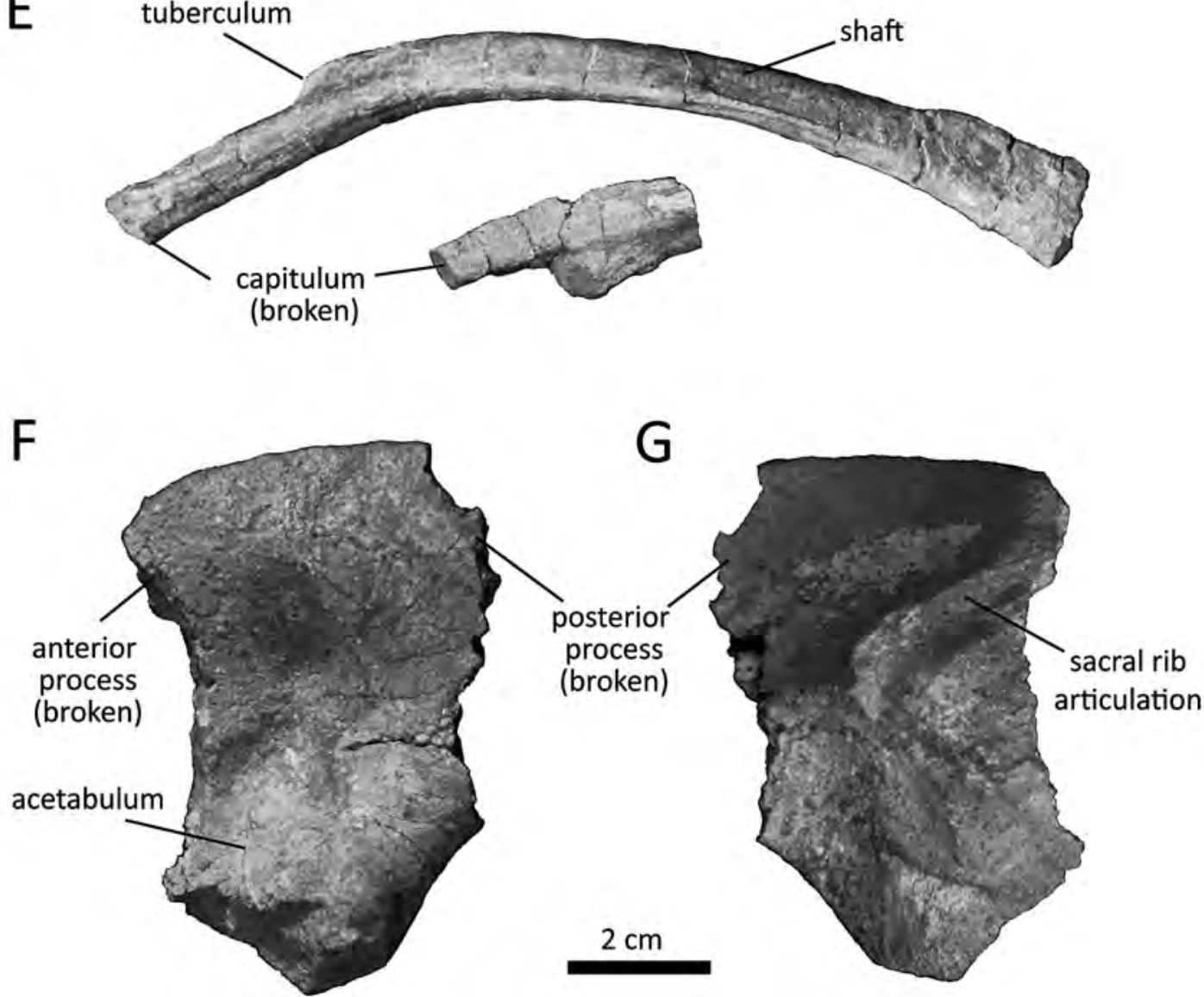

Fig. 3. Crocodyliform remains from the Kaninah Formation, tentatively referred to Atoposauridae; A: Isolated tooth in buccal view showing ziphodont morphology with serrated carinae. Section at A' shows buccolingually compressed profile; B: Same tooth in lingual view. Inset B' shows detail of denticles; C-D: Isolated vertebra in (C) dorsal and (D) caudal views; E: Partial posterior dorsal ribs in cranial view; F-G: Partial left ilium in lateral (F) and medial (G) views. 


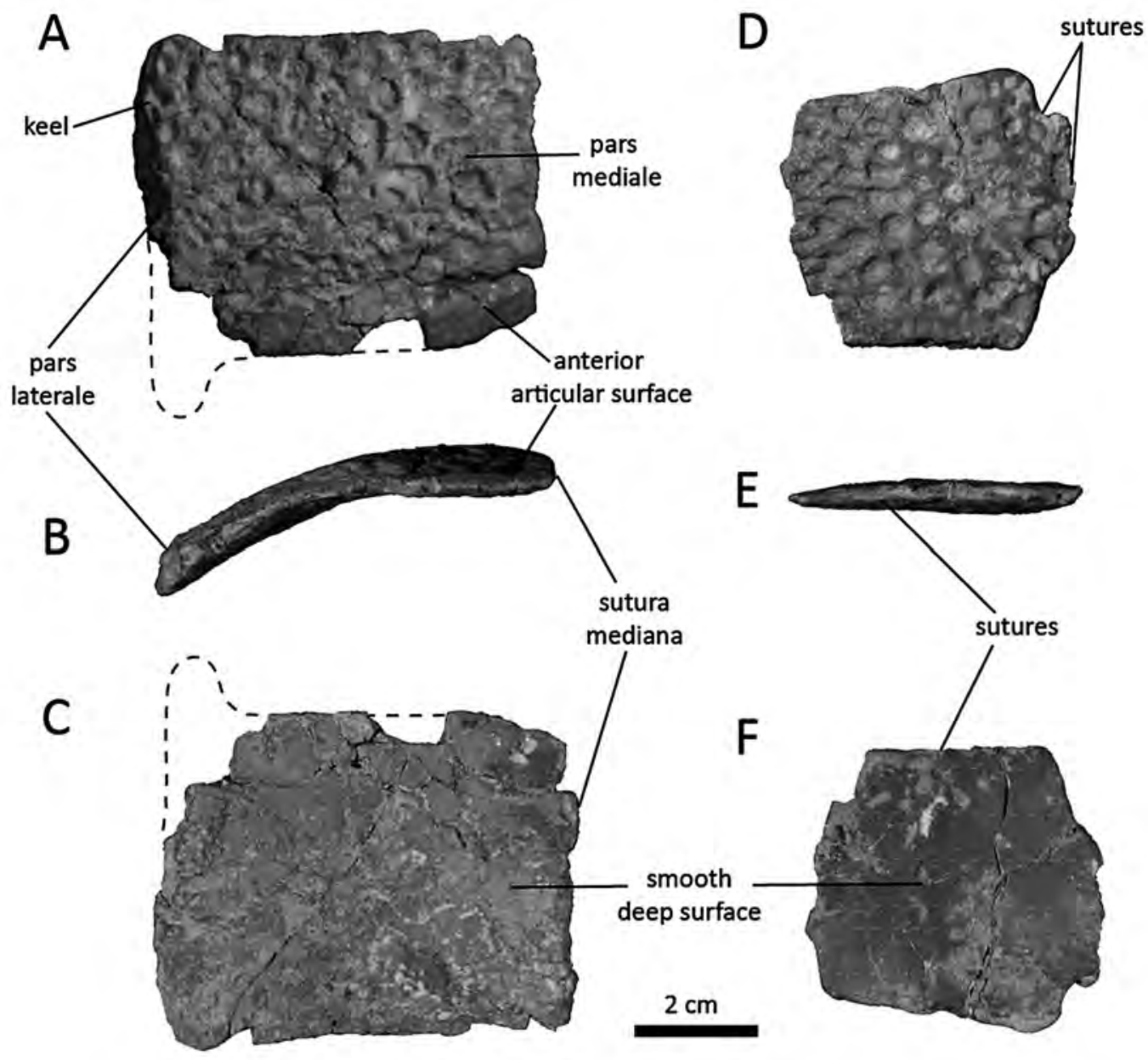

Fig. 4. Osteoderm morphology from Kaninah crocodyliforms.

A-C: Isolated paramedian osteoderm from biserial dorsal shield in (A) dorsal, (B) cranial, and (C) ventral views; dashed lines indicate inferred position of the craniolateral process.

D-F: Isolated osteoderm from gastral shield in (A) ventral, (B) marginal, and (C) dorsal views.

The right dorsal paramedian osteoderm (Fig. 4A-C) is wider mediolaterally than it is long. In axial view, it is curved about a craniocaudal axis, creating a convex deep surface. The strong curvature suggests that this osteoderm originated from the transitional cervical or caudal regions, where the radius of axial curvature is smaller than in the mid-dorsal region. The superficial surface is ornamented with deep, subcircular pits. A well-developed, smooth anterior articular surface is separated from the ornamented region by a shallow groove. Breakage obscures the base of the craniolateral process, but it appears that a small one existed. A modestly developed keel is located far laterally and separates the superficial surface into a small lateral part (= pars laterale) and a much larger medial part (= pars mediale). These ar- eas are not strongly angled relative to one another, suggesting an open paravertebral shield (cf. Salisbury \& Frey, 2001). Wide, rectangular dorsal osteoderms with reduced or absent keels are known in dyrosaurids and gavialoids (e.g., Schwarz et al., 2006).

The median suture (= sutura mediana) is preserved, indicating a tight midline articulation between this osteoderm and its contralateral counterpart, and demonstrating that it comes from the right side. The lateral margin is gently rounded and does not show evidence of a suture. This strongly suggests that the osteoderms were arranged in two parasagittal rows, thereby contributing to a biserial paravertebral shield.

The gastral osteoderm (Fig. 4D-F) is roughly trapezoidal in shape, with two subparallel, 
straight sides and two irregular margins. At least three of these borders have sutures, indicating that the osteoderm articulated with several others in a gastral shield. It is flat in axial and lateral views. The superficial surface is ornamented with deep, subcircular pits, whereas the deep surface is smooth. This polygonal form of the gastral osteoderm is common in non-eusuchian mesoeucrocodylians.

\section{Discussion}

Here we describe the most complete vertebrate material from the middle Eocene Kaninah Formation of Yemen, comprising a collection of crocodyliform dental and postcranial elements. The ziphodont tooth morphology, together with the biserial paravertebral shield organization and polygonal gastral osteoderm, are generally consistent with a mesoeucrocodylian, likely within selected ziphodontan notosuchians. However, the possibly procoelous anterior caudal vertebra associated with the dental and integumentary elements argues against this. Although the poor preservation of the centrum renders the exact characterisation of the central articular facets incomplete, the partially preserved posterior articular surface of the centrum appears to form a convex margin, strongly suggesting that the succeeding vertebra in the series would have exhibited an anteriorly concave (i.e., procoelous) centrum. Although procoelous vertebrae have historically been associated with Eusuchia, they have also been identified in certain non-eusuchian mesoeucrocodylians such as atoposaurids. If procoelous, the vertebra taken together with the ziphodont tooth and osteoderm organisation are most consistent with the suite of characteristics exhibited by atoposaurids.

The Atoposauridae form a clade of small-bodied (dwarf) crocodyliforms first known from Late Jurassic and/or Early Cretaceous strata in Western Europe (Buscalioni \& Sanz, 1988, 1990). The group is represented by Brillanceausuchus from the Early Cretaceous of Cameroon (Michard et al., 1990; Martin et al., 2010), and isolated, atoposaurid-like teeth have been discovered in North America. Recently, craniodental remains pertaining to the atoposaurid Theriosuchus were discovered in Thailand (Lauprasert et al., 2011), with additional specimens from Romania extending the clade into the Late Cretaceous (Martin et al., 2010). If the Kaninah material indeed represents an atoposaurid, this discovery would represent the first occurrence of the group from the Arabian Peninsula, and would constitute the first Cenozoic occurrence of Atoposauridae, indicating that at least a representative atoposaurid (or atoposaurid lineage) survived the end-Cretaceous extinction event.

Among crocodyliforms, several clades are known to have survived this event. These include dyrosaurids, goniopholidids, and trematochampsids (e.g., Markwick, 1998; Hill et al., 2008). The discovery of an atoposaurid crocodyliform in the middle Eocene would further corroborate the hypothesis that crocodyliform lineages did not universally experience a diversity crises caused by the event (Markwick, 1998; Fara, 2000). This discovery would also imply a temporal extension for the clade of $\sim 30$ million years, suggesting that additional diversity within the clade may remain to be found in strata of intervening ages, which is not entirely implausible considering the recent temporal extension of the clade into the Late Cretaceous (Martin et al., 2010). Alternatively, given the relative paucity of information from the middle Eocene of Afro-Arabia, the combination of characteristics exhibited by the Kaninah crocodyliform may in fact represent a poorly known form exhibiting a character mosaicism as yet unrecognised among crocodyliforms. Testing among these alternative hypotheses awaits discovery of more complete materials.

\section{Conclusions}

Until recently, the continental record of Palaeogene vertebrates from the Arabian Peninsula extended no earlier than the Oligocene, with anurans described from the late Oligocene Yemen Volcanic Group (Henrici \& Baez, 2001), and a more diverse fauna recovered from early Oligocene deposits in the Ashawq Formation of Oman (e.g., Thomas et al., 1989; Seiffert et al., 
2012). More recently, an anthropoid primate was described from the mid-late Oligocene Shumaysi Formation of Saudia Arabia (Zalmout et al., 2010), and the discovery of a large-bodied mammal in the Aydim Formation of Oman has for the first time revealed continental mammals from as early as the late Eocene (Al-Sayigh et al., 2008).

Fossils recovered from the Middle Eocene Kaninah Formation constitute the earliest Palaeogene record of continental vertebrates from the Arabian Peninsula, thereby offering the first glimpse at the region's fauna subsequent to the end-Cretaceous extinction event. During the Cenozoic, the Arabian plate separated from continental Africa and assumed a closer geographic relationship with Eurasia. Hence, the vertebrate fossil record of the Arabian Peninsula also holds keys for understanding the sequence and timing of faunal interchanges that occurred as a result of major tectonic events, with a shift from a primarily Afro-Arabian fauna in the Palaeogene to a more cosmopolitan fauna in the Neogene during its time as a 'crossroads' for biogeographic dispersals (Flynn \& Jacobs, 1999; Winkler, 1992, 1994). The crocodyliform at Kaninah offers the intriguing hypothesis of a long-surviving atoposaurid in the region, or perhaps the presence of an altogether unknown crocodyliform with a unique combination of morphological features.

In any case, preservation of associated materials at Kaninah raises new questions and offers promise for additional discoveries that may better document the region's role in revealing relictual forms, first occurrences, and evidence of faunal dispersals across the Arabian landmass. Work in Kaninah and in the vast expanse of continental deposits farther west is the focus of ongoing work by the Yemen Paleontology Project, with the aim of further documenting Cenozoic vertebrate evolutionary history throughout the region.

\section{Acknowledgements}

We thank all who helped to make this research possible. Reconnaissance work received funding from a variety of sources. We thank the Geological Survey of Yemen for providing 4WD field vehicles, including drivers and petrol. Additional financial support for the project was generously provided by a private donor. We appreciate the logistical and scientific efforts of Dr Fahd Abdullah Afif (Yemen Geological Survey - Mukalla) and Basheer Al-Botaily (Yemen Geological Survey - GSMRB Yemen National Science Museum Project). Peer reviews by Steven Salisbury and Joseph Sertich were invaluable, and greatly improved the initial manuscript. We also appreciate helpful insights and comments provided by Alan Turner.

\section{References}

Al-Sayigh, A.R., Nasir, S., Schulp, A.S. \& Stevens, N.J., 2008. The first described Arsinoitherium from the Eocene Aydim Formation of Oman: biogeographic implications. Paleoworld 17, 41-46.

As-Saruri, M.L., 1995. Lateral lithologic change of the Habshiyah Formation (Middle Eocene) on southern Arabian Peninsula (Yemen). Abstract volume 'Rift sedimentation and tectonics, Red Sea-Gulf of Aden region' Meeting (Sana'a, Yemen, 23-31 October 1995), 58.

As-Saruri, M.L., 1996. Lithostratigraphic subdivision of the Tertiary sediments of the Republic of Yemen. Yemen Stratigraphic Commission, Sana'a, Yemen, 12 pp.

As-Saruri, M.L., 1998. Lithostratigraphic subdivision of the Middle Eocene of Southern Arabian Peninsula (Republic of Yemen). Zeitschrift für Geologische Wissenschaften 26, 684-695.

As-Saruri, M.L., 1999. Lithostratigraphie der Tertiär-Sedimente der Republik Jemen. Schriftenreihe für Geologische Wissenschaften 10, 131 pp.

As-Saruri, M.L. \& Langbein, R., 1994. Über einen marinterrestrischen Faziesübergang im Mitteleozän des Jemen. Abstract volume 'Sediment 94, Greifswalder Geowissenschaftliche Beiträge', Greifswald, 1994, 10-12.

As-Saruri, M.L. \& Langbein, R., 1995. Die mitteleozäne Habshiyah Formation auf der südlichen Arabischen Halbinsel. Zentralblatt für Geologie und Paläontologie 1, 161-174.

As-Saruri, M.L., Whybrow, P.J. \& Collinson, M.E., 1998. Discovery of fruits, seeds and vertebrates in the Kaninah and Mayfa'ah Formations (Middle Eocene), Republic of Yemen. Zeitschrift für Geologische Wissenschaften 26, 697-703.

As-Saruri, M.L., Whybrow, P.J. \& Collinson, M.E., 1999. Geology, fruits, seeds and vertebrates (?Sirenia) from the Kaninah Formation (Middle Eocene), Republic of Yemen. [In:] P.J. Whybrow \& A. Hill (Eds): Fossil Vertebrates of Arabia. Yale University Press, New Haven, 441-451.

Benton, M.J. \& Clark, J.M., 1988. Archosaur phylogeny and the relationships of the Crocodylia. [In:] M.J. Benton (Ed.): The phylogeny and classification of the tetrapods. Clarendon Press, Oxford, 295-338.

Beydoun, Z.R., 1966. Eastern Aden Protectorate and part of Dhufar. United States Geological Survey Professional Paper 560-H, 49 pp. 
Beydoun, Z.R. \& As-Saruri, M.L., 1998. Phanerozoic depositional basins and inter-basinal highs of Yemen: their structural framework and sedimentary cover. Zeitschrift für Geologische Wissenschaften 26: 517-529.

Beydoun, Z.R., As-Saruri, M.L. \& Baraba, R.S., 1996. Sedimentary basins of the Republic of Yemen: their structural evolution and geological characteristics. Revue de l'Institute Français du Pétrole 51, 763-775.

Beydoun, Z.R., As-Saruri, M.L., El-Nakhal, H., Al-Ganad, I.N., Baraba, R.S., Nani, A.O. \& Al-Aawah, M.H., 1998. International lexicon of stratigraphy, Republic of Yemen: v. III, Asia, fascicule, 10b2. IUGS Publication 34, 245 pp. Doi: 10.1017/S001675689922290X.

Buscalioni, A.D. \& Sanz, J.L., 1988. Phylogenetic relationships of the Atoposauridae (Archosauria, Crocodylomorpha). Historical Biology 1, 233-250.

Buscalioni, A.D. \& Sanz, J.L., 1990. The family Atoposauridae: an approach to the history of dwarf crocodiles. Treballs del Museu de Geologia de Barcelona 1, 77-89.

Fara, E., 2000. Diversity of Callovian-Ypresian (Middle Jurassic-Eocene) tetrapod families and selectivity of extinctions at the K/T boundary. Geobios 33, 387-396.

Flynn, L.J. \& Jacobs, L.L., 1999. Late Miocene small-mammal faunal dynamics: the crossroads of the Arabian Peninsula. [In:] P.J. Whybrow \& A. Hill (Eds): Fossil vertebrates of Arabia. Yale University Press, New Haven, 410-419.

Gervais, P., 1871. Remarques au sujet des reptiles provenant des calcaires lithographiques de Cerin, dans le Bugey, qui sont conservés au Musée de Lyon. Comptes Rendus des séances de I'Académie de Sciences 73: 603-607.

Henrici, A.C. \& Baez, A.M., 2001. First occurrence of Xenopus (Anura: Pipidae) on the Arabian Peninsula: a new species from the upper Oligocene of Yemen. Journal of Paleontology 75, 870-882.

Hill, R.V., McCartney, J.A., Roberts, E., Bouaré, M., Sissoko, F. \& O'Leary, M.A., 2008. Dyrosaurid (Crocodyliformes: Mesoeucrocodylia) fossils from the Upper Cretaceous and Paleogene of Mali: implications for phylogeny and survivorship across the K/T/boundary. American Museum Novitates 3631, 1-19.

Huxley, T.H., 1875. On Stagonolepis robertsoni, and on the evolution of the Crocodilia. Quarterly Journal of the Geological Society 31, 423-438.

Jacobs, L.L., Murry, P.A., Downs, W.R. \& El-Nakhal, H.A., 1998. A dinosaur from the Republic of Yemen. [In:] P.J. Whybrow \& A. Hill (Eds): Fossil vertebrates of Arabia. Yale University Press, New Haven, 454-459.

Lauprasert, K., Laojumpon, C., Saenphala, W., Cuny, G., Thirakhupt, K. \& Suteethorn, V., 2011. Atoposaurid crocodyliforms from the Khorat Group of Thailand: first record of Theriosuchus from southeast Asia. Paläontologische Zeitschrift 85, 37-47.

Markwick, P.J., 1998. Crocodilian diversity in space and time: the role of climate in paleoecology and its implication for understanding K/T extinctions. Paleobiology 24, 470-497.

Martin, J.E., Rabi, M. \& Csiki, Z. 2010. Survival of Theriosuchus (Mesoeucrocodylia: Atoposauridae) in a Late Cretaceous archipelago: a new species from the Maastrichtian of Romania. Naturwissenschaften 97, 845-854.
Michard, J.G, De-Broin, F., Brunet, M. \& Hell, J., 1990. Le plus ancien crocodilien néosuchien spécialisé à caractères 'eusuchiens' du continent africain (Crétacé inférieur, Cameroun). Comptes Rendus Academie Sciences Paris 311, 365-371.

Salisbury, S.W., Molnar, R.E., Frey, E. \& Willis, P.M.A., 2006. The origin of modern crocodyliforms: new evidence from the Cretaceous of Australia. Proceedings of the Royal Society of London B 273, 2439-2448.

Salisbury, S. \& Frey, E., 2001. A biomechanical transformation model for the evolution of semi-spheroidal articulations between adjoining vertebral bodies in crocodilians. [In:] G.C. Grigg, F. Seebacher \& C.E. Franklin (Eds): Crocodilian biology and evolution. Surrey Beatty \& Sons, Chipping Norton, NSW, 85-134.

Schulp, A.S., Al-Wosabi, M. \& Stevens, N.J., 2008. First dinosaur tracks from the Arabian Peninsula. Public Library of Science - ONE, http:/ / www.plosone.org/ article/info:doi\%2F10.1371\%2Fjournal.pone.0002243.

Schwarz, D., Frey, E. \& Martin, T., 2006. The postcranial skeleton of the Hyposaurinae (Dyrosauridae; Crocodyliformes). Palaeontology 49, 695-718.

Seiffert, E.R., Nasir, S., Al-Harthy, A., Groenke, J.R., Kraatz, B.P., Stevens, N.J. \& Al-Sayigh, A.R., 2012. Diversity in the later Paleogene proboscidean radiation: a small barytheriid from the Oligocene of Dhofar Governorate, Sultanate of Oman. Naturwissenschaften 99, 133-141.

Thomas, H., Roger, J., Sen, S., Pickford, M., Gheerbrant, E., Al-Sulaimani, Z. \& Al-Busaidi, S., 1989. Oligocene and Miocene terrestrial vertebrates in the southern Arabian Peninsula (Sultanate of Oman) and their geodynamic and palaeogeographic significance. [In:] P.J. Whybrow \& A. Hill (Eds): Fossil vertebrates of Arabia. Yale University Press, New Haven, 430-442.

Whetstone, K.N. \& Whybrow, P.J., 1983. A "cursorial" crocodilian from the Triassic of Lesotho (Basutoland), southern Africa. Occasional Papers of the University of Kansas Museum of Natural History 106, 1-37.

Winkler, A.J., 1992. Systematics and biogeography of middle Miocene rodents from the Muruyur beds, Baringo district, Kenya. Journal of Vertebrate Paleontology 12, 236-249.

Winkler, A.J., 1994. The middle/upper Miocene dispersal of major rodent groups between southern Asia and Africa. [In:] Y. Tomida, C.K. Li \& T. Setoguchi (Eds): Rodent and lagomorph families of Asian origins and diversification. National Museum of Nature and Science Monographs, Tokyo 8: 173-184.

Zalmout, I.S., Sanders, W.J., MacLatchy, L.M., Gunnell, G.F., Al-Mufarreh, Y.A., Ali, M.A., Nasser, A.-A.H., Al-Masari, A.M., Al-Sobhi, S.A., Nadhra, A.O., Matari, A.H., Wilson J.A. \& Gingerich, P.D., 2010. New Oligocene primate from Saudi Arabia and the divergence of apes and Old World monkeys. Nature $466,360-364$.

Manuscript received: 6 September 2012 Revision accepted: 17 June 2013 